\title{
Palaeogronotoma n. gen. from the Miocene of Spain, the first Tertiary fossil record of the subfamily Eucoilinae (Hymenoptera: Figitidae)
}

\author{
Enrique PEÑALVER \\ Museo Geominero, Instituto Geológico y Minero de España, \\ c/ Ríos Rosas, 23, E-28003 Madrid (Spain) \\ e.penalver@igme.es \\ Félix M. FONTAL-CAZALLA \\ Área Anardi n 5, E-20730, Azpeitia, Guipuzcoa (Spain) \\ felix.fontal@tecnalia.com \\ Juli PUJADE-VILLAR \\ Universitat de Barcelona, Facultat de Biologia, \\ Departament de Biologia Animal (Artròpodes), \\ Avda. Diagonal, 645, E-08028 Barcelona (Spain) \\ jpujade@ub.edu
}

KEY WORDS

Insecta,

Hymenoptera,

Eucoilinae,

Early Miocene,

Spain,

new genus,

new species.
Peñalver E., Fontal-Cazalla F. M. \& Pujade-Villar J. 2013. - Palaeogronotoma n. gen. from the Miocene of Spain, the first Tertiary fossil record of the subfamily Eucoilinae (Hymenoptera: Figitidae). Geodiversitas 35 (3): 643-653. http://dx.doi.org/10.5252/g2013n3a7

\section{ABSTRACT}

From the extensive fossil record of insects found in the Early Miocene of the Rubielos de Mora basin (Teruel Province, Spain) a single, well-preserved specimen of the subfamily Eucoilinae Thomson, 1862 (Hymenoptera: Cynipoidea: Figitidae) has been identified. The palaeoentomological site of Rubielos de Mora is a Konservat-Lagerstätte constituted by lacustrine oil-shales. The specimen is the first fossil Eucoilinae from a Tertiary outcrop and it represents a new genus and species of a family (Figitidae Thomson, 1862) extremely scarce in the fossil record: Palaeogronotoma nordlanderi $\mathrm{n}$. gen, $\mathrm{n}$. sp. The genus belongs to Gronotoma group (Diglyphosemini Belizin, 1961 tribe) and it is closely related to the genus Gronotoma Förster, 1869, from which mainly differs in the antennal configuration, which is especially well preserved, although other diagnostic characters are studied in this paper. 


\begin{abstract}
RÉSUMÉ
Palaeogronotoma $n$. gen. du Miocène de l'Espagne, la première registre fossile tertiaire de la sous-famille Eucoilinae (Hymenoptera: Figitidae).

Un spécimen unique bien préservé de la sous-famille Eucoilinae Thomson, 1862 (Hymenoptera: Cynipoidea: Figitidae) a été identifié dans la collection considérable de fossiles d'insectes trouvés dans le Miocène inférieur du bassin de Rubielos de Mora (province de Teruel, Espagne). Le site paléoentomologique du Rubielos de Mora est un Konservat-Lagerstätte de rythmites bitumineux et lacustres. Il s'agit du premier fossile d'Eucoilinae connu d'un affleurement tertiaire. Il représente un nouveau genre et une nouvelle espèce de la famille

MOTS CLÉS

Insecta,

Hymenoptera,

Eucoilinae,

Miocène inférieur,

Espagne,

genre nouveau, espèce nouvelle.

Figitidae Thomson, 1862, très rare dans les archives fossiles, Palaeogronotoma nordlanderi n. gen, n. sp. Le genre appartient au groupe Gronotoma et est proche du genre Gronotoma Förster, 1869 (tribu Diglyphosemini Belizin, 1961), qui se distingue principalement dans la configuration des antennes, particulièrement bien conservées, bien que d'autres caractères diagnostiques sont étudiés dans la présente étude.
\end{abstract}

\section{INTRODUCTION}

The superfamily Cynipoidea Latreille, 1802 comprises eight families, three of them recently described or re-described by Liu et al. (2007) are known exclusively as fossils. The named "microcynipoids" proposed by Ronquist (1995) comprise according to Liu et al. (2007) the extinct family Gerocynipidae Liu \& Engel, 2007 and the living families Figitidae Thomson, 1862 and Cynipidae Latreille, 1802. Figitidae includes 13 subfamilies (Liu et al. 2007; RosFarré \& Pujade-Villar 2007; Buffington \& Liljeblad 2008), two of them (Paleocynipinae Kovalev, 1995 and Rasnicynipinae Kovalev, 1996) only known as fossils (Grimaldi \& Engel 2005; Liu et al. 2007).

The subfamily Eucoilinae Thomson, 1862 (sensu Ronquist 1995; Fontal-Cazalla et al. 2002; Buffington et al. 2007; Díaz et al. 2007) is the most species-rich figitid subfamily, currently with about 80 genera and 1000 species (Ronquist 1999). In some ecosystems eucoilines can be the most abundant and diverse cynipoids, particularly in the Neotropics, and they occur in all the biogeographic regions (Fergusson 1995; Nieves-Aldrey \& Fontal-Cazalla 1997a, b; Fontal-Cazalla \& Nieves-Aldrey 1999, 2004). Traditionally, the substantial evidence of the monophyly of the group has been the presence of a scutellar plate with a glandular release pit in the dorsal surface of the scutellum (Ronquist 1999). In many classical works this group was considered a subfamily of the family Cynipidae (Dalla Torre \& Kieffer 1910; Weld 1952). After 1950, its taxonomic status has changed from family (Quinlan 1979; Nordlander 1982a, 1984; Kovalev 1995) to subfamily of the Figitidae (Riek 1971; Rasnitsyn 1980, 1988; Ronquist 1995). After Ronquist (1995), there is consensus to consider Eucoilinae as a subfamily of Figitidae (Fontal-Cazalla et al. 2002). The eucoiline monophyly is currently supported by six synapomorphies: 1) malar sulcus present (Character 18:1; Fontal-Cazalla et al. 2002: fig. 8D); 2) four-segmented maxillary palps having the two basal segments fused (character 45:1; Fontal-Cazalla et al. 2002: figs 8C, 9A); 3) maxillary palps with distal segments without pubescence (character 49:1; Fontal-Cazalla et al. 2002: fig. 9F); 4) mesopleuron with single, straight carina (character 92:2; Fontal-Cazalla et al. 2002: fig. 10B, D); 5) mechanosensory hair patch of articular bulb of petiole situated medioventrally (character 134:1); and 6) modified median part of scutellum raised to form an elevated scutellar plate (character 77:2).

The biology of Figitidae is poorly known. They are larval parasitoids of dipterans, homopterans, 
neuropterans and other hymenopterans, while others are hyperparasitoids of braconid and chalcidoid primary parasitoids of aphids and psyllids (Fergusson 1986; Gauld \& Bolton 1988; Goulet \& Huber 1993; Fergusson 1995; Liu et al. 2007). The Eucoilinae are larval parasitoids of a wide variety of schizophoran Diptera, including phytophagous species of Tephritidae Newman, 1834, Chloropidae Rondani, 1856 and Agromyzidae Fallén, 1823. They are common parasitoids of Sepsidae Walker, 1833, Sphaeroceridae Macquart, 1835, Drosophilidae Rondani, 1856, Ephydridae Zetterstedt, 1837, Phoridae Curtis, 1833, Muscidae Latreille, 1802, Calliphoridae Brauer \& Bergenstamm, 1889 and Sarcophagidae Macquart, 1834, among others, present in animal dung, carrion, rotting fruit and vegetation, birds' nests and so on (Fergusson 1995).

The world fossil record of cynipoids is particularly poor (Liu et al. 2007). All Cretaceous cynipoids are of parasitoid families, maybe with the exception of the specimens belong to the extinct family Gerocynipidae and the cynipid Tanaoknemus Liu \& Engel, 2007 described from Canadian amber, Alberta, Late Cretaceous (Campanian) in age (Grimaldi \& Engel 2005; Liu et al. 2007). The first record of the family Figitidae is from the Upper Cretaceous (Turonian). In the subfamily Eucoilinae, only three genera and species have been described in the fossil record: Anteucoila delicia Liu \& Engel, 2007 from Canadian amber, Syneucoila magnifica Liu \& Engel, 2007 and Jerseucoila plesiosoma Liu \& Engel, 2007 from Raritan amber, New Jersey, Late Cretaceous (Turonian) in age (Liu et al. 2007). Labandeira (1994) cited this subfamily in an unpublished data base printout of the Miocene Dominican amber arthropod taxa, held in the collections of the Departments of Paleobiology in the Smithsonian Institution, but there are no available studies of the specimen(s); Zherikhin et al. (2009) cite three specimens in these collections based on the identification done by Alexander Rasnitsyn. All this fossil record has been found in amber, a good medium to preserve in detail minute insects. Herein we describe one specimen of the subfamily Eucoilinae as a compression fossil, from the Early Miocene lacustrine oil-shales of the Rubielos de Mora Basin in Spain, as a new genus and species.

\section{GEOLOGY AND TAPHONOMY}

The Early Miocene deposits of the Rubielos de Mora Basin (Province of Teruel) in eastern Spain are rich in fossil insects. This basin is limited by normal faults and located in the south-east of the Iberian Chain. The fossil insects appear in oilshales originated in a stratified (meromictic) lake. Bioturbation has not been observed. There are four important palaeoentomological outcrops in this basin. From them, "Río Rubielos" outcrop, located at the east of the Rubielos de Mora village, is the richest in fossil insects (Peñalver 1998, 2002, 2007; Martínez-Delclòs et al. 1991; Montoya et al. 1996; Peñalver et al. 1999; Anadón et al. 2003). The outcrop Río Rubielos 2 (RR2) was excavated in September 1994 at which time over 800 specimens of insects and plants were obtained (a portion of the insects from the RR2 locality were monographed by Peñalver 1998). The aphid Greenideoida turolensis Wegierek \& Peñalver, 2002, the halictid bee, Halictus petrefactus Engel \& Peñalver, 2006, and the megaspilid wasp, Conostigmus lazaros Peñalver \& Engel, 2006 (Wegierek \& Peñalver 2002; Engel \& Peñalver 2006; Peñalver \& Engel 2006), were found during this excavation, and the stratigraphic log for the RR2 outcrop was discussed in Engel \& Peñalver (2006).

On the other hand, the taphonomical characteristics are typical of a Konservat-Lagerstätte (Peñalver \& Seilacher 1995). Some interesting taphonomical features of the fossil insects are: 1) a low decay degree; 2) a large amount of articulated specimens; 3) a good preservation of very delicate external structures, for example ommatidia, microtrichia and scales; 4) preservation of internal organs (spermathecae); and 5) preservation of wing colour patterns.

The order Hymenoptera is the dominant insect group in the Rubielos de Mora fossil record with the exception of Diptera and Thysanoptera orders. The Chalcidoidea, Vespoidea (only ants), and Ichneumonoidea are the best represented groups for Hymenoptera, and four species have been described from the uncommon families in the fossil record Halictidae, Perilampidae and Megaspilidae (Engel \& Peñalver 2006; Peñalver \& Engel 2006). 
Cynipoidea is only represented in the fossil record of Rubielos de Mora by one specimen of the subfamily Eucoilinae found during the palaeontological excavation carried out in RR2.

\section{METHODS}

The carbonaceous film that constitutes the specimen had cracks (in some parts of the mesosoma and metasoma), due to the dehydration of the material after exposure and preparation, and it was treated with a hardening agent (Peñalver 1998, 2002).

Material was studied under ethanol.

The drawing was made with a camera lucida. Photomicrography used a digital camera attached to a stereomicroscope Olympus BX51.

The used terminology is adopted from Nordlander (1982b) and Goulet \& Huber (1993).

\section{SYSTEMATIC PALAEONTOLOGY}

Order HYMENOPTERA Linnaeus, 1758

Superfamily CYNIPOIDEA Latreille, 1802

Family Figitidae Thomson, 1862

Subfamily Eucoilinae Thomson, 1862

Tribe Diglyphosemini Belizin, 1961

\section{Genus Palaeogronotoma n. gen.}

TYPE SPECIES. - Palaeogronotoma nordlanderi n. sp., by present designation.

DERIVATION OF NAME. - The generic name indicates the morphological resemblance with Gronotoma Förster, 1869. Gender neutral.

INCLUDED SPECIES. - Monotypic genus.

OCCURRENCE. - Early Miocene of Spain.

Diagnosis. - Female antenna 13-segmented, longer than mesosoma, the segment 3 two times longer than segment 4, whit a 6-segmented club. Notaulices broadened basally and convergent towards the scutellum. Lower part of mesopleuron smooth, polished. Mesopleural ridge present. Pronotal plate not projected to pronotum. Fore wings long, rounded apically, surface pubescent with apical hair fringe. Forewing with radial cell closed. Base of metasoma without a ring of pubescence.

\section{Palaeogronotoma nordlanderi $\mathrm{n} . \mathrm{sp}$.}

(Figs 1;2)

Holotype. - Alate adult MPZ-97/547 (additional number RM-RR-276), in a small slab of oil-shale with dimensions $4 \times 3 \times 0.3 \mathrm{~cm}$, housed in Museo de Paleontología de la Universidad de Zaragoza (Zaragoza, Spain). Specimen in lateral position, virtually complete and well preserved, having lost only some portions of the wings and the mesosoma (some of the legs and one antenna are overlapped under the body). The same surface with the holotype also contains a Mycetophilidae (Diptera) of the genus Exechia (MPZ-96/19) (currently on a separate portion of the original slab) and shells of ostracods.

Derivation of name. - The new species is named after Dr. Göran Nordlander, specialist in Cynipoidea. The epithet nordlanderi is in the genitive case.

TYPE HORIZON. - Specimen discovered in lacustrine oil-shales from the Early Miocene (Early Burdigalian) of Rubielos de Mora Basin (Iberian Chain).

Type locality. - "Río Rubielos 2" outcrop, Rubielos de Mora village, Teruel Province, Spain.

DiAgNosis. - As for genus.

\section{DESCRIPTION (EXCLUDING}

THE DIAGNOSTIC CHARACTERS)

Body dark and large, $1.5 \mathrm{~mm}$ long (Fig. 2A). Female antenna with 6-segmented club; club segments distinguished by presence of rhinaria (Fig. 2C, D). Antenna $1.11 \mathrm{~mm}$ long. Measures of the antennal segments (length $\times$ width, in $\mathrm{mm}$ ) are: $\mathrm{S} 1: ? \times 0.06, \mathrm{~S} 2: 0.03 \times 0.04, \mathrm{~S} 3$ : $0.10 \times 0.02, S 4: 0.05 \times 0.03, S 5: 0.06 \times 0.03$, S6: $0.06 \times 0.03, S 7: 0.07 \times 0.03, S 8: 0.07 \times 0.05, S 9:$ $0.08 \times 0.04$, S10: $0.08 \times 0.04$, S1 $1: 0.07 \times 0.05$, S12: $0.07 \times 0.05$, S13: $0.15 \times 0.07$. Mesosoma $0.59 \mathrm{~mm}$ long and $0.57 \mathrm{~mm}$ high (Fig. 2A, E). Estimated forewing length $1.38 \mathrm{~mm}$. Radial cell closed on front margin and about two times longer than wide (internal measures) (Fig. 2B). Hind leg $1.32 \mathrm{~mm}$ long (femur about $0.34 \mathrm{~mm}$, tibia $0.46 \mathrm{~mm}$, tarsus $0.52 \mathrm{~mm}$ ). Metasoma, $0.78 \mathrm{~mm}$ long and $0.65 \mathrm{~mm}$ high, with the segment 1 obscured by segment 2 , that occupies the main visible part of metasoma (Fig. 2A). Metasomal segments 3, 4 and 5 visible. 


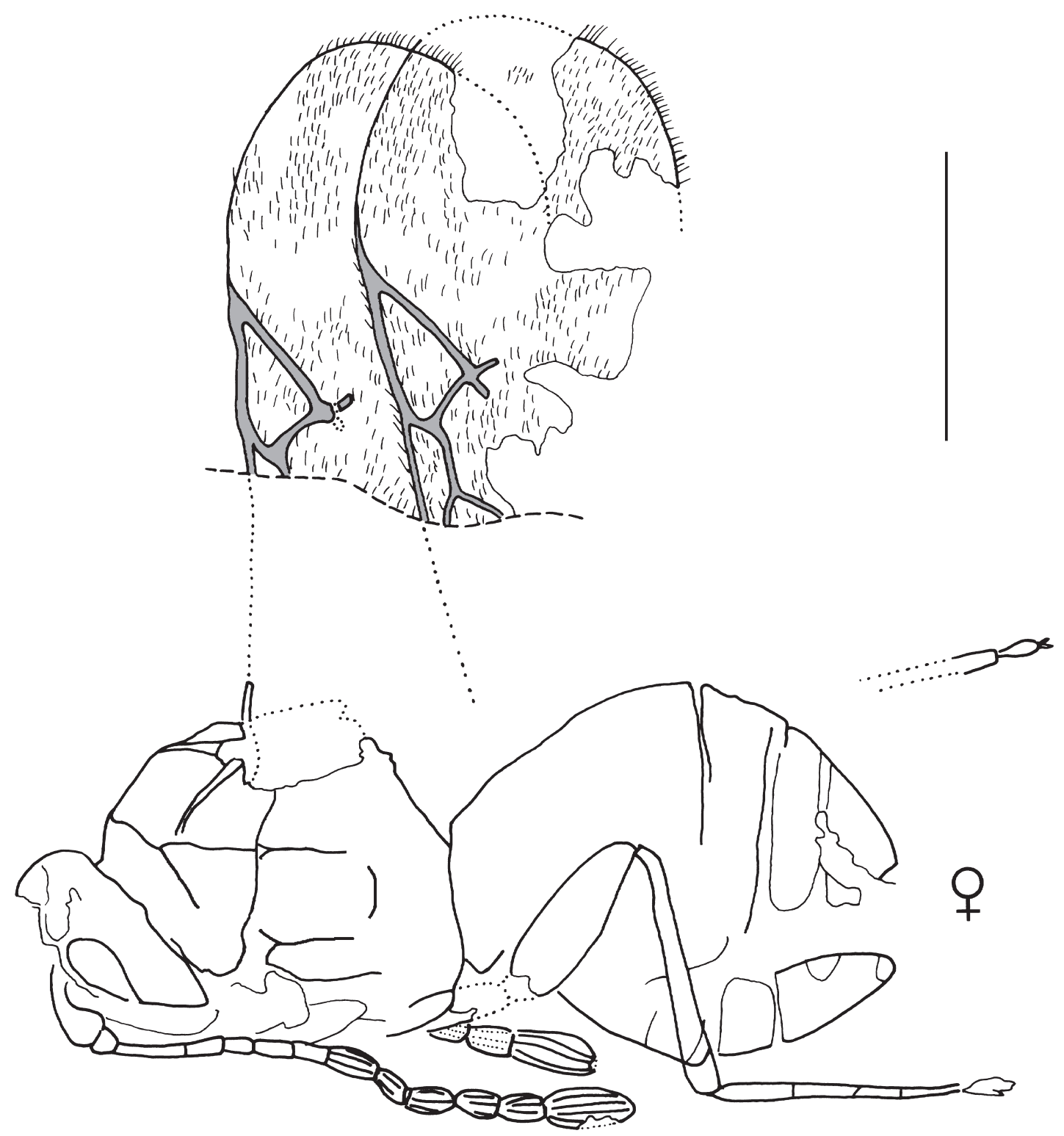

FIG. 1. - Palaeogronotoma nordlanderi n. gen., n. sp. (Hymenoptera: Figitidae: Eucoilinae), MPZ-97/547. Scale bar: 0.5 mm.

\section{PALAEOBiology}

Unknown, but all recent genera closely related to this new genus are parasitoids of Agromyzidae (Diptera). The family Agromyzidae is commonly referred to as the leaf-miner flies, for the feeding habit of larvae, most of which are leaf miners on various plants. No agromyzid adult specimens or leaves with distinctive leaf-mines by agromyzids have been identified from the Rubielos de Mora fossil record up to now. Diptera, the most abundant and diverse group in Rubielos de Mora site containing 13 families identified, was monographed 
by Peñalver (2002), but several fossil specimens of small morphotypes remained unstudied and many others were found later, thus possibly the family Agromyzidae is also recorded.

\section{DISCUSSION}

The fossil presents a typical Cynipoid wing pattern: wing apical part wider, pubescence in general in the entire wing surface, cilia on the apical margin, wing venation reduced, presence of a typical triangular small radial cell, and absence of a pterostigma (Figs 1;2). The small size and the lateral body habitus indicate that the specimen here studied is a microcynipoid. Both, the presence of an antennal club and a large abdomen are female characters. The eucoiline synapomorphies listed above and the presence of a scutellar plate with a glandular release pit are characters difficult to see in our fossil. However, the following list of characters, the main part of them are well visible in the fossil specimen (Figs $1 ; 2$ ), indicates that it belongs to the subfamily Eucoilinae:

- female with 13-segmented antennae, having flagellum 11-segmented and antennal club (Fig. 2C, D); - mesonotum with notaulices (Figs 1; 2E);

- presence of syntergum (fusion of the abdominal terga 3-5 in females [Figs 1;2A]); it is the only morphological apomorphy shared by the Figitidae subfamilies Eucoilinae and Pycnostigminae Cameron, 1905 (Ronquist 1999). Although the syntergum present in the fossil specimen apparently is shorter within Eucoilinae, we have checked carefully this character in order to discard a misinterpretation due to an artefact;

- absence of a secondary sclerotized small cell (Fig. 2B): This character is the only apomorphy of Pycnostigminae (Character 129:1, cf. fig. 11A in Fontal-Cazalla et al. 2002) and the specimen herein illustrated has a different radial cell (Fig. 2B); - mesopleuron with a straight carina (Fig. 2C); it is the only eucoiline synapomorphy, but this character has been not observed with confidence. We observed a special fracture that possibly corresponds to the weak cuticular zone constituted by the carina.

Nordlander studied the systematics of some groups of eucoiline genera (Nordlander 1976,
1978, 1980, 1981, 1982a, b). He divided the Eucoilinae in six informal groups (Nordlander 1982b): Gronotoma group (the most plesiomorphic group), Trybliographa group, Rhoptromeris group, Chrestosema group, Ganaspis group and Kleidotoma group (the most apomorphic group). Posteriorly, phylogenetic analyses (Fontal-Cazalla et al. 2002; Buffington et al. 2007), were used to make a formal classification. A fuller discussion of the rationale for tribal recognition was given in Forshage et al. (2008). Recently, the European tribes have been established (Forshage \& Nordlander 2008): Diglyphosemini Belizin, 1961; Eucoilini Thomson, 1862; Trichoplastini Kovalev, 1989; Ganaspini Belizin, 1961 and Kleidotomini Hellén, 1960. It is important to note that, currently, the characterization of some Eucoilinae tribes is in constant revision, mainly due to new phylogenetic analyses.

According to Forshage \& Nordlander (2008) the specimen described here belongs to tribe Diglyphosemini. This tribe coincides with the "Gronotoma group" in the analyses of Fontal-Cazalla et al. (2002) and Buffington et al. (2007), and partly with the "Gronotoma group" of Nordlander (1982b). According to Forshage \& Nordlander (2008), Diglyphosemini is morphologically characterized by: 1) absence of a ring of pubescence in the base of metasoma; 2) presence of notauli on mesoscutum (as deep furrows or series of deep subcontiguous pits); and 3) anterior (basal) part of pronotal plate subvertical, not protruding, and glandular pit on scutellar plate more or less centrally placed (not observed in the fossil specimen). In addition (Thomson 1862; Förster 1869; Nordlander 1976), the genera included in this tribe have the fore wings with rounded apexes, the scutellar plate large, and female with antennae longer than mesosoma and antennal segments 3 and 4 equal-subequal in length. Other common characters of the "Gronotoma group" are the presence of a pronotal plate not projected to pronotum, fore wings pubescent, and a mesopleural suture complete.

According to Forshage \& Nordlander (2008), the tribe Diglyphosemini includes four genera in the European area: Microstilba Förster, 1869; Disorygma 

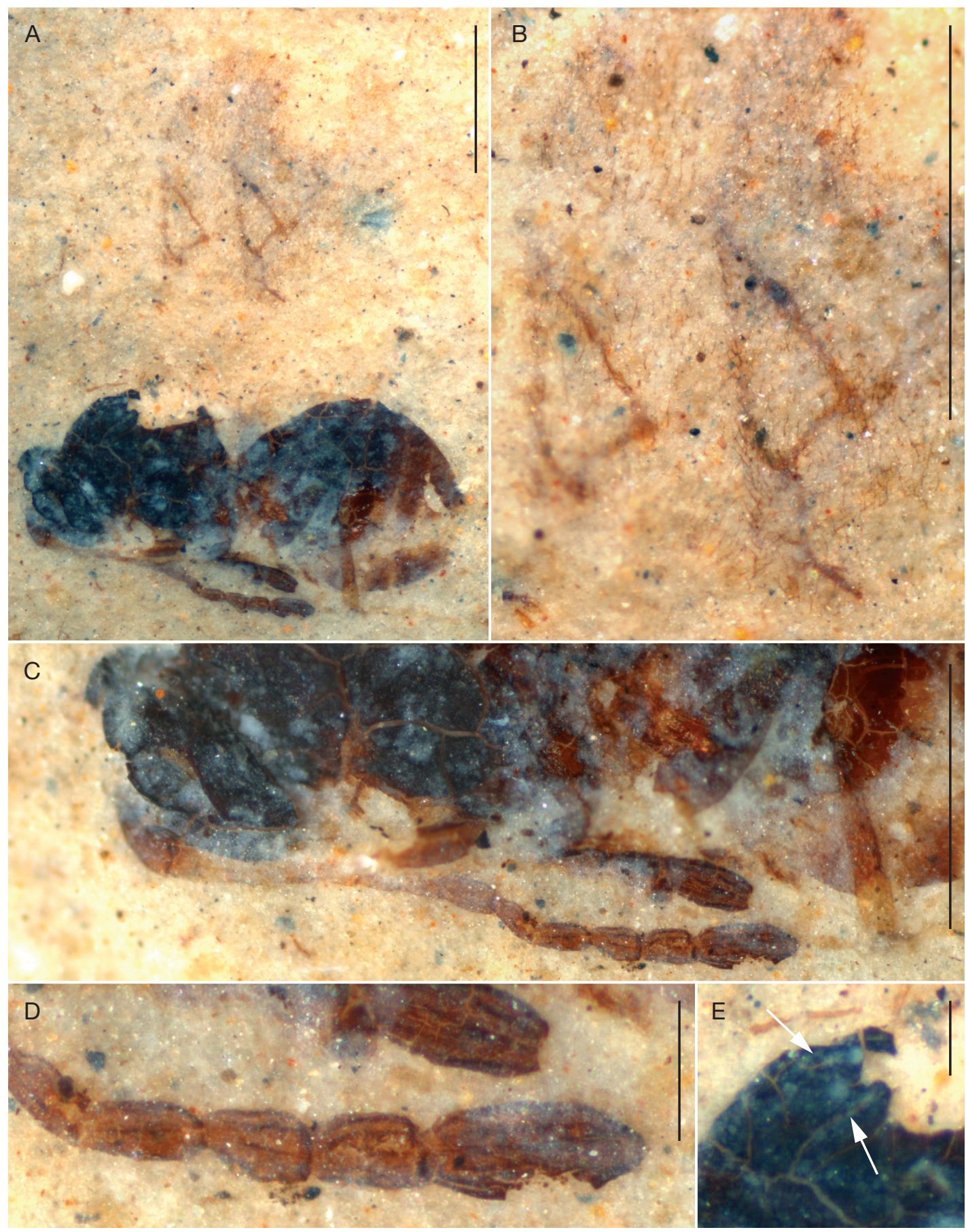

FIG. 2. - Photomicrographs of Palaeogronotoma nordlanderi n. gen., n. sp. (Hymenoptera: Figitidae: Eucoilinae) MPZ-97/547 taken under ethanol: A, general view of the fossil; $\mathbf{B}$, detail of the fore wing veins; $\mathbf{C}$, head and antennae; $\mathbf{D}$, detail of the antennal club showing the rhinaria; E, detail of the mesosoma (arrows indicate the notaulices). Scale bars: A, B, $0.5 \mathrm{~mm}$; C, $0.4 \mathrm{~mm}$; D, E, $0.1 \mathrm{~mm}$. 
Förster, 1869; Diglyphosema Förster, 1869 and Gronotoma Förster, 1869. A comparative study indicates that the fossil has an exclusive combination of characters (Table 1). Palaeogronotoma n. gen. is closely related to Gronotoma and Diglyphosema because all these genera have strongly convergent and complete notauli. The fossil runs to Gronotoma using the keys of Weld (1952) and Forshage \& Nordlander (2008) because the radial cell is closed, the size is less than $2 \mathrm{~mm}$ and the mesosoma is very short and stout (not clearly longer than high). The generic name of the new genus tries to indicate this morphological resemblance.

The new genus can be distinguished mainly by the length of female antennal segments 3 and 4
(Table 1). This feature has a systematic meaning at generic level, as it is possible to check it when we study the diagnostic characters of Glauraspidia Thomson, 1862 males that have been used in several keys (Weld 1952; Quinlan 1978). Also can be differentiated by the presence of antennal club in females; in the fossil record this character has only been observed in specimens of the tribe Diglyphosemini.

To include Palaeogronotoma n. gen. in Weld's key of 1952, the only study with an identification key to World genera, using also the data published in Forshage \& Nordlander (2008), it should apply the following emendation in page 217 couples 70 and 71.

\section{REVISED KEY FOR THE INCLUSION OF PALAEOGRONOTOMA N. GEN.}

70. Marginal cell open (R1 absent). Scutellar plate elongate, posteriorly protruding to hind margin of scutellum. Size slightly larger (c. $2 \mathrm{~mm}$ or more), mesosoma clearly longer than high Diglyphosema Förster, 1869

- Marginal cell closed (R1 present). On non-extinguished species, scutellar plate less elongate, posteriorly not reaching hind margin of scutellum (scutellum protruding posteriorly further than scutellar plate). Smaller size (less than $2 \mathrm{~mm}$ ), mesosoma very short and stout, not clearly longer than high 71

71. Lower part of mesopleuron aciculate-coriaceous. Female antennae with the segment 3 and 4 equal-subequal in length. Antennal club absent. Extant genus (no fossils known). Gronotoma Förster, 1869

- Lower part of mesopleuron smooth. Female antennae with the segment 3 two times longer than 4. Antennal club present. Fossil genus (Early Miocene; $19 \mathrm{Ma}$ )

Palaeogronotoma n. gen.

\section{CONCLUSIONS}

Palaeogronotoma $\mathrm{n}$. gen. belongs to Diglyphosemini tribe and it is close to the extant genus Gronotoma.

The Cretaceous eucoilines described by Liu et al. (2007) attest the antiquity of the lineage, but younger fossils have been unknown up to now. The specimen here studied is the first fossil of the subfamily Eucoilinae found in Tertiary deposits. Because the fossil record of this subfamily is notably poor, and of the family Figitidae and the whole cynipoids as well, the recovery of eucoiline remains from new deposits is of significance. Minute hymenopterans are common in Rubielos de Mora fossil record, mainly chalcidoids, and surely they are also common in other similar compression deposits with exceptional preservation. The poor knowledge of the geological history of cynipoids surely is a consequence of the small size of these hymenopterans which makes their detection during palaeontological excavations and their subsequent study very difficult, although the preservation in amber is optimal. Similar biases in the study and the knowledge of the geological history of other groups of small insects occur.

\section{Acknowledgements}

We thank Alexandr P. Rasnitsyn, Dany Azar and Annemarie Ohler for their useful criticisms and corrections. We are grateful to Instituto de Estudios 
TABLE 1. - Comparative analysis of the genera of the group Gronotoma (except to Zaeucoila and including Palaeogronotoma n. gen.). See Hedicke (1930), Quinland $(1986,1988)$ and Nordlander (1976). Abbreviations: Notauli: *, convergent towards scutellum; +, parallel; -, absent. Radial cell: +, closed; -, open. Mesopleuron: +, aciculate-coriaceous; -, smooth. Antennal club: +, present; -, absent.

\begin{tabular}{|c|c|c|c|c|c|c|}
\hline Genera & Synonymic names & Notauli & Radial cell & $\begin{array}{l}\text { Meso- } \\
\text { pleuron }\end{array}$ & $\begin{array}{c}\text { Antennal } \\
\text { club }\end{array}$ & $\begin{array}{c}\text { Relation } \\
\text { A3/A4 }\end{array}$ \\
\hline $\begin{array}{l}\text { Gronotoma } \\
\text { Förster, } 1869\end{array}$ & $\begin{array}{l}\text { Eucoilidea } \\
\text { Ashmead, } 1887 \\
\text { in Hedicke (1930: 75) } \\
\text { Afrostilba Benoit, 1956 } \\
\text { in Quinlan (1986: 259) }\end{array}$ & * & + & + & - & 1 \\
\hline $\begin{array}{l}\text { Diglyphosema } \\
\text { Förster, } 1869\end{array}$ & $\begin{array}{l}\text { Amphiglyphosema } \\
\text { Benoit, } 1956 \\
\text { in Quinlan (1988: 173) }\end{array}$ & * & - & - & - & 1 \\
\hline \multirow[t]{2}{*}{$\begin{array}{l}\text { Disorygma } \\
\text { Förster, } 1869\end{array}$} & $\begin{array}{l}\text { Ectolyta Förster, } 1869 \\
\text { in Nordlander (1976: 72) }\end{array}$ & + & $\begin{array}{c}- \\
\text { (in Disorygma sensu } \\
\text { stricto and in morpho- } \\
\text { type Ectolyta) }\end{array}$ & - & - & 1 \\
\hline & $\begin{array}{l}\text { Erisphagia Förster, } 1869 \\
\text { in Nordlander (1976: 72) }\end{array}$ & $\begin{array}{l}- \\
\text { (in the morpho- } \\
\text { types Ectolyta } \\
\text { and Erisphagia) }\end{array}$ & $\begin{array}{c}+ \\
\text { (in morphotype } \\
\text { Erisphagia) }\end{array}$ & - & - & 1 \\
\hline $\begin{array}{l}\text { Microstilba } \\
\text { Förster, } 1869\end{array}$ & & + & + & - & - & 1 \\
\hline $\begin{array}{l}\text { Palaeogronotom } \\
\text { n. gen. }\end{array}$ & & * & + & - & + & 2 \\
\hline
\end{tabular}

Turolenses and Diputación General de Aragón for financial support and permit, respectively, for the palaeontological excavation, to Museo de Paleontología de la Universidad de Zaragoza for permission to study the specimen, to G. Nordlander of Swedish University of Agricultural Sciences (Uppsala, Sweden) and M. Forshage of Department of Systematic Zoology, Evolutionary Biology Centre (Uppsala, Sweden), for their reviews and suggestions for the manuscript and to M. A. Alonso Zarazaga of the Museo Nacional de Ciencias Naturales (Madrid, Spain) for his advises about the Nomenclature.

\section{REFERENCES}

Anadón P., Peñalver E. \& Alcalá L. 2003. - Exceptional fossil sites in Neogene basins of the central Iberian Chain (Teruel and Rubielos de Mora basins). Congress Field trip Guide, EPA-Workshop 2003, Exceptional Preservation, Teruel: 123-169.

Buffington M. L. \& Liljeblad J. 2008. — The description of Euceroptrinae, a new subfamily of Figitidae
(Hymenoptera), including a revision of Euceroptres Ashmead, 1896 and the description of a new species. Journal of Hymenoptera Research 17 (1): 44-56.

Buffington M. L., Nylander J. A. A. \& Heraty J. 2007. - The phylogeny and evolution of Figitidae (Hymenoptera: Cynipoidea). Cladistics 23: 1-29.

Dalla Torre K. W. \& KiefFer J. J. 1910. — Cynipidae. Tierreich 24: 1-891.

Díaz N. B., Gallardo F. E., Gaddi A. L., Jiménez M., Ros-Farré P., Paretas-Martínez J. \& PujadeVILlar J. 2007. - Avances en el conocimiento de las Figitidae neotropicales (Hymenoptera: Cynipoidea), in LlORENTE-BOUSQUETS J. \& LANTERI A. (eds), Contribuciones taxonómicas en órdenes de insectos hiperdiversos. Las Prensas de Ciencias, Universidad Nacional Autónoma de México, Mexico D.F.: $141-158$.

Engel M. S. \& Peñalver E. 2006. - A Miocene Halictine Bee from Rubielos de Mora Basin, Spain (Hymenoptera: Halictidae). American Museum Novitates 3503: 1-10.

Fergusson N. D. M. 1986. - Charipidae, Ibaliidae \& Figitidae (Hymenoptera: Cynipoidea). Handbooks for the identification of British Insects 8, Part 1c, Royal Entomological Society of London, $55 \mathrm{p}$. 
FErGusson N. D. M. 1995. - Cynipoid families, in Hanson P. E. \& Gauld I. D. (eds), The Hymenoptera of Costa Rica. Oxford University Press, Oxford: 247-265.

Fontal-Cazalla F. M. \& Nieves-Aldrey J. L. 1999. Preliminary data on comparative abundance and diversity of eucoilines (Hymenoptera: Figitidae: Eucoilinae) from temperate and tropical areas, in DEBARRO P. (ed.), 4th International Hymenopterists Conference, 6-11th January 1999, Canberra, Australia, Program and Abstracts, International Society of Hymenopterists, Canberra, 66 p.

Fontal-Cazalla F. M. \& Nieves-Aldrey J. L. 2004. Estudio comparado de diversidad de eucoilinos paleárticos (El Ventorrillo, España) y neotropicales (P. N. Coiba, Panamá) (Hymenoptera, Cynipoidea, Figitidae, Eucoilinae). Boletín de la Sociedad Entomológica Aragonesa 35: 51-101.

Fontal-CaZAlla F. M., Buffington M. L., Nordlander G., Liljeblad J., Ros-Farré P., Nieves-Aldrey J. L., Pujade-Villar J. \& Ronquist F. 2002. — Phylogeny of the Eucoilinae (Hymenoptera: Cynipoidea: Figitidae). Cladistics 18: 154-199.

Forshage M. \& Nordlander G. 2008. - Identification key to European genera of Eucoilinae (Hymenoptera, Cynipoidea, Figitidae). Insect Systematics \& Evolution 39: 341-359.

Forshage M., NORDLANDER G. \& RONQUIST F. 2008. Quasimodoana, a new Holarctic genus of eucoiline wasps (Hymenoptera, Cynipoidea, Figitidae), with a phylogenetic analysis of related genera. Systematic Entomology 33 (2): 301-318.

FÖRSTER A. 1869. - Über die Gallwespen. Verhandlungen der Zoologisch-Botanischen Gesellschaft in Wien 19: 327-370.

Gauld I. D. \& Bolton B. 1988. - The Hymenoptera. British Museum, London, $332 \mathrm{p}$.

Goulet H. \& Huber J. T. 1993. - The Hymenoptera of the World: An Identification Guide to Families. Research Branch, Agriculture Canada, Ottawa, 668 p.

Grimaldi D. A. \& Engel M. 2005. - Evolution of the Insects. Cambridge University Press, New York, $755 \mathrm{p}$.

HedicKe H. 1930. - Beiträge zur Kenntnis der Cynipides. (Hym.) VI. Zur Synonymie einiger Anacharitinen, Eucoelinen u. Figiten. Deutsche Entomologische Zeitschrift 1930: 74-76.

Kovalev O. V. 1995. — Paleontological History, Phylogeny, and Systematics of Brachycleistogastromorpha, Infraorder N., and Cynipomorpha Infraorder N. (Hymenoptera) with descriptions of new fossil and recent Families, Subfamilies and Genera. Entomological Review 74 (4): 105-147.

LABANDEIRA C. C. 1994. - A compendium of fossil insect families. Milwaukee Public Museum Contributions in Biology and Geology 88: 1-71.
Liu Z., Engel M. S. \& Grimaldi D. A. 2007. — Phylogeny and geological history of the cynipoid wasps (Hymenoptera: Cynipoidea). American Museum Novitates 3583: 1-48.

Martínez-Delclòs X., Peñalver E. \& Belinchón M. 1991. - Primeras aportaciones al estudio de los insectos del Mioceno de Rubielos de Mora, Teruel (España). Revista Española de Paleontología no extra: 125-137.

Montoya P., Peñalver E., Ruiz-Sánchez F. J., SantisteBan C., AlCalá L., Belinchón M. \& Lacomba J. I. 1996. - Los yacimientos paleontológicos de la cuenca terciaria continental de Rubielos de Mora (Aragón). Revista Española de Paleontología no extra.: 215-224.

Nieves-Aldrey J. L. \& FonTAl-CaZAlla F. M. 1997a. Inventario de los Himenópteros parasitoides (Cynipoidea y Chalcidoidea, Hymenoptera, Insecta) de la isla de Coiba (Panamá), in Castroviejo S. (ed.), Flora y Fauna del Parque Nacional de Coiba (Panamá), Inventario preliminar. Agencia Española de Cooperación Internacional, Madrid: 375-397.

Nieves-Aldrey J. L. \& Fontal-Cazalla F. M. 1997b. Los insectos de la isla de Coiba (Panamá). Abundancia y dinámica estacional. Análisis del caso de los himenópteros (Hexapoda, Hymenoptera), in CASTROVIEjo S. (ed.), Flora y Fauna del Parque Nacional de Coiba (Panamá), Inventario preliminar. Agencia Española de Cooperación Internacional, Madrid: 329-361.

NordLANDER G. 1976. — Studies on Eucoilidea (Hym., Cynipoidea) I. A revision of the north-western European species of Cothonaspis Htg. with description of new species and notes on some other genera. Entomologisk Tidskrift 97: 65-77.

NordLander G. 1978. - Revision of the genus Rhoptromeris Förster, 1869 with reference to north-western European species. Studies on Eucoilidea (Hym., Cynipoidea) II. Entomologica Scandinavica 9: 47-62.

NorDLANDER G. 1980. - Revision of the genus Leptopilina Förster, 1869, with notes on the status of some other genera (Hymenoptera, Cynipoidea: Eucoilidae). Entomologica Scandinavica 11: 428-453.

NordLANDER G. 1981. - A review of the genus Trybliographa Förster, 1869 (Hymenoptera, Cynipoidea: Eucoilidae). Entomologica Scandinavica 12: 381-402.

NORDLANDER G. 1982a. - Identities and relationships of the previously confused genera Odonteucoila, Coneucoela and Trichoplasta (Hymenoptera, Cynipoidea: Eucoilidae). Entomologica Scandinavica 13: 269-292.

NordLANDER G. 1982b. - Systematics and Phylogeny of an Interrelated Group of Genera Within the Family Eucoilidae (Insecta: Hymenoptera, Cynipoidea). PhD thesis, University of Stockholm, 34 p. [unpublished].

NoRDLANDER G. 1984. - Vad vet vi om parasitiska Cynipoidea? [What do we know about parasitic Cynipoidea?] Entomologisk Tidskrift 105: 36-40. 
Peñalver E. 1998. - Estudio tafonómico y paleoecológico de los insectos del Mioceno de Rubielos de Mora (Teruel). Instituto de Estudios Turolenses, Teruel, $179 \mathrm{p}$.

Peñalver E. 2002. - Los insectos dipteros del Mioceno del Este de la Península Ibérica; Rubielos de Mora, Ribesalbes y Bicorp. Tafonomía y sistemática. PhD thesis, University of Valencia, 550 p. [published as pdf file in cd-rom format].

PEÑALVER E. 2007. - Insect palaeofauna of the Rubielos de Mora Basin (Lower Miocene, Northeast Spain), in Delclòs X. \& Soriano C. (eds), Mesozoic and Cenozoic Spanish insect localities. Field Trip Guide Book. Diputación Foral de Álava, Álava: 32-47.

Peñalver E. \& Seilacher A. 1995. - Rubielos de Mora- Eine untermiozäne Fossil-Lagerstätte. Fossilien 1995 (4): 211-216.

Peñalver E. \& Engel M. 2006. — Two Wasp Families Rare in the Fossil Record (Hymenoptera): Perilampidae and Megaspilidae from the Miocene of Spain. American Museum Novitates 3540: 1-12.

Peñalver E., De Santisteban C. \& Barrón E. 1999. Fossil insects and palaeobotany of the Rubielos de Mora Basin (Teruel), in MeléNDEZ G. \& SORIA-Llop C. (eds), The Geological and Paleontological Heritage of Central and Eastern Iberia (Iberian Range, Spain). Publicaciones del Seminario de Paleontología de Zaragoza, Zaragoza: 95-116.

Quinlan J. 1978. — Hymenoptera: Cynipoidea: Eucoilidae. Handbooks for the identification of British Insects, Vol 8, Part 1b, Royal Entomological Society of London, $58 \mathrm{p}$.

QUINLAN J. 1979. - A revisionary classification of the Cynipoidea (Hymenoptera) of the Ethiopian Zoogeographical Region. Aspiceratinae (Figitinae) and Oberthuerellinae (Liopteridae). Bulletin of the British Museum (Natural History), Entomology series 39 (2): 85-133.

QUINLAN J. 1986. - A key to the Afrotropical genera of Eucoilidae (Hymenoptera), with a revision of certain genera. Bulletin of the British Museum (Natural History), Entomology series 52 (4): 243-366.

QUINLAN J. 1988. - A revision of the Afrotropical genera of Eucoilidae (Hymenoptera). Bulletin of the British Museum (Natural History), Entomology series 56 (4): 171-229.

RASNITSYN A. P. 1980. - Proiskhozhdenie I evolyutsiya pereponchatokrylykh nasekomykh [Origin and evolution of the Hymenoptera]. Trudy Paleontologicheskogo Instituta Akademiya Nauk SSSR 123: 1-196 [in Russian].

RASNITSYN A. P. 1988. - An outline of evolution of the hymenopterous insects (order Vespida). Oriental Insects 22: 115-145.

RIEK E. F. 1971. - A new subfamily of cynipoid wasps (Hymenoptera: Cynipoidea) from Australia, in ASAHina S., GressitT J. L., Hidaka Z., Nishida T. \& Nomura K. (eds), Entomological Essays to Commemorate the Retirement of Professor K. Yasumatsu. Hokuryukan Publ. Co., Tokyo: 107-112.

RONQUIST F. 1995. - Phylogeny and early evolution of the Cynipoidea (Hymenoptera). Systematic Entomology 20 (4): 309-335.

RONQUIST F. 1999. - Phylogeny, classification and evolution of the Cynipoidea. Zoologica Scripta 28 (12): 139-164.

Ros-Farré P. \& Pujade-Villar J. 2007. — Plectocynipinae, a new subfamily of Figitidae and description of a new Neotropical genus of Thrasorinae (Hymenoptera: Cynipoidea). Zootaxa 1583: 1-13.

Thomson C. G. 1862. — Försök till uppställning och beskrifning av Sveriges Figiter. Öfversigt af Kongl Vetenskaps-Akademiens Förhandlingar 18: 395-420.

WELD L. H. 1952. — Cynipoidea (Hym.) 1905-1950. Privately printed, Ann Arbor, Michigan, $351 \mathrm{p}$.

WegIEREK P. \& PEÑAlVER E. 2002. — Fossil representatives of the family Greenideidae (Hemiptera, Aphidoidea) from the Miocene of Europe. Geobios 35: 745-757.

ZherikHin V. V., SuKacheva I. D. \& Rasnitsyn A. P. 2009. - Arthropods in contemporary and some fossil resins. Paleontological Journal 43: 987-1005. 